\title{
Innovation and Technology needs for the oil and gas industry in Peru
}

\author{
Christ Barriga $\mathrm{P}^{1}$., Lesly Aliaga G. ${ }^{1}$, Jorge Bermejo N. ${ }^{1}$, Pamela Catari C. ${ }^{1}$, Romina Martinez S. ${ }^{1}$, Mauricio \\ Valdivia Ch. ${ }^{1}$ \\ ${ }^{1}$ National University of Moquegua \\ Corresponding Author: cbarrigap@unam.edu.pe
}

\section{SUMMARY}

Peru experienced the oil rush due to the discovery of reserves, but since the Camisea project was found in the Cuzco region, oil has been in decline, Peru is rated to low competitiveness rates below countries such as Ecuador and Colombia.

The hydrocarbons sector accounted for $54 \%$ of the total energy tender in 2012 . The oil and gas industry has advanced technologically. Today, the technological challenges are focused on taking advantage of unconventional resources having a strong focus on process safety, environmental management, and fuel quality. In a new era of high volatility in the oil and gas price, technology is crucial to maximize the value; among them, the Modernization Project of the Talara Refinery and its process are announced. Peru is perfecting technologies to take advantage of gas and oil that is difficult to access, so that its role in the Peruvian economy is fundamental.

Keywords -- Innovation, oil, gas, technology.

\section{INTRODUCTION}

The oil and gas production worldwide has a great energy demand. Significant changes towards new forms of exploration and production of hydrocarbons entail a great technological and environmental challenge. Today, technological challenges are focused on exploiting unconventional resources, increasing the recovery of existing fields, and using the increasingly powerful and portable resources of mass computing and wireless technologies (J. Sakr, R. Pallini, 2018).

Peru has witnessed important changes in the hydrocarbon industry during the last 20 years, taking into account the discovery of the natural gas reserve at Camisea in the Cuzco region causing an energy revolution in Peru. The consumption of oil was displaced along with other primary energies due to its good development possibilities (J. Sakr, R. Pallini, 2018).

One of the great challenges facing Peru in this economic boom of the pandemic that further aggravates the difficult situation that the upstream (a sector that explores and produces hydrocarbons) in Peru was going through. Indeed, from January to July, the price of an oil barrel fell by about 29\%, from US \$57.5 to US \$40.7. This makes the development of hydrocarbon exploration and production activities in Peru unfeasible. One of the great challenges is to issue measures that allow current investments to be retained and their viability to be achieved, and to attract new investments and develop more fields (Sociedad Privada de Hidrocarburos, 2021).

A Talara Refinery Modernization (PMRT) project is proposed, which brings with it new knowledge and technology, thus generating innovation in the scheme of the industrial refining process, describing the facilities, dispatch, storage, process units and auxiliary units (Carlos Paredes. 2019).

\section{THEORETICAL FRAMEWORK}

\subsection{National and International Background}

In the 1970s, Peru experienced the oil rush over the discovery of oil reserves in the northern jungle. The country was considered an oil export region with a production of 200,000 barrels of crude oil per day (200 mbpd). From 1980 to later years, there was a reduction in oil production and mostly in investments. 


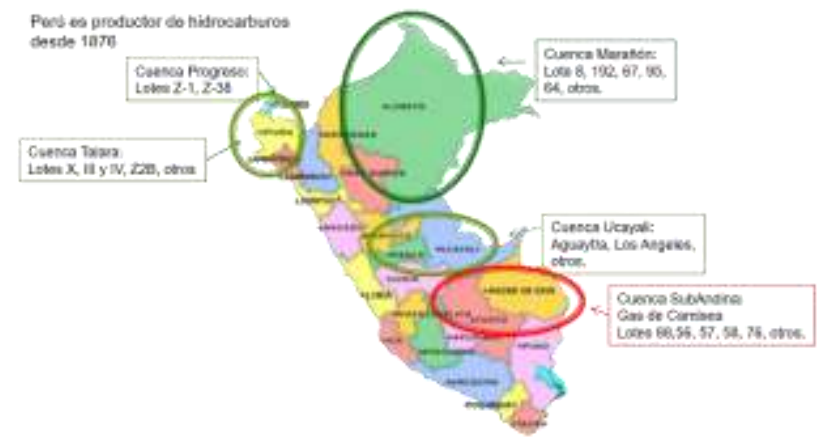

Figure 1: Hydrocarbons in Peru

According to Checa (2008), with the technological development of industry and society, there is currently a commitment to an approach to industrial security based on the search for the common good, a dynamic consideration of security, a perspective that can be integrated into it, with other social systems, interactions and coordination in the process of the different risks, specialized treatment of risk factors and an integrative approach of different disciplines. (Czech, 2008)

The discovery of the Camisea oil reserves in the Cuzco region caused an energy revolution in Peru. Oil consumption was displaced along with other primary energies due to its good development possibilities. Thanks to the impulse of the State, the Camisea project made its way by making a framework for promoting its consumption, which caused a modification in the country's primary energy matrix (Tamayo, Salvador, Vásquez and De la Cruz, 2015).

Figure 2 shows the oil production from 1971 to 2013. The figure shows how oil production has been declining since the peak reached in 1979 , and this is due to the lack of security and incentives in exploration investments.

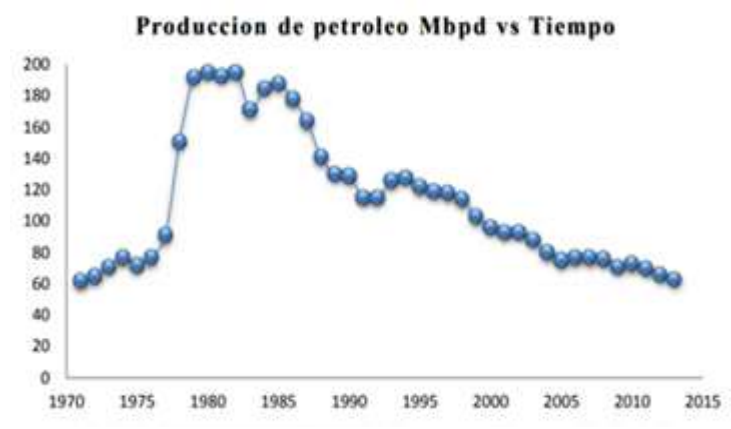

Figure 2: Oil Production Mbps vs time.

Hawkins (2007), affirms that at present the company consists of a complex system that is located in the deep structures that make up our society: production technologies, competitiveness of the labor market, globalization of the economy, information and communication technologies. These relationships are subject to the uncertainty that characterizes companies in their success in making decisions and management aimed at achieving the proposed objectives, and that uncertainty, in turn, is more characterized by the dynamism and accelerated change that preside over the activities of the current company. (Hawkins, 2007).

Although the science of climate change is uncertain, there is no doubt about the considerable damage to society that would result from reducing the availability of fuel to consumers through the adoption of Kyoto Protocol or other mandatory measures that would significantly increase the cost of energy. Most economists tell us that such a step would damage our economy and almost certainly require large increases in taxes on gas and oil. It could also involve large transfers of wealth to other countries (Exxon Mobil CEO and Chairman Lee Raymond, 2001). 
The Fraser Institute is conducting surveys of oil company executives on investment barriers in different countries and researches the competitiveness of various countries in hydrocarbon investments. This competitiveness is measured by an index of political perception and these are based on royalties, geological data, environmental policies, the regulatory framework, and above all political stability of the country. The Fraser Institute ranks Peru with competitiveness indices below countries such as Ecuador and Colombia. (Fraser Institute Global Petroleum Survey, 2017).

\subsection{Theoretical Foundations}

Liquid hydrocarbons have played an important role in economic activities in the country. The sector accounted for 54\% of total energy consumption in 2012 and remained the main source of energy within local production processes and economic activities. In this context, it is relevant to measure the characteristics of the local sector within the global panorama and identify the implications of international oil shocks in the local market (OSINERGMIN, 2015).

Environmental control technology (ECT) is one of the technologies integrated into the prevention process. Within the broader scope of environmental technology that includes environmental impact assessment, remediation, and prevention, TEC is primarily related to prevention and risk assessment. Historically, developments in preventive techniques came after analytical and remediation measures, which are inadequately reactive and progressively expensive (Stefan Orszulik, 2016).

Definitely, the operation and Maintenance Services Sector in oil and gas is one of the most demanding, dynamic, creative, innovative, and advanced sectors. The action of maintenance and operation ensures the production processes so that they are not interrupted, frequently affecting production, causing costs not contemplated in the financial models. The loss of production due to the lack of maintenance on operations can directly impact the oil and gas industry, generating losses attributable to maintenance and poor operation. Therefore, the operation and Maintenance Services Sector in oil and gas is not the only Sector in which the natural technical person "can solve everything". It is a sector that adds value to the operating companies by avoiding large losses by maintaining a balanced operation and maximizing the value of their assets, which translates into profitability for the business. This aspect is key in the extraction and production of oil and gas, not only because it ensures the integrity of productive assets, but also ensures the operational reliability and integrity of team operators with operators, coordinators, and supervisors who help them improve productivity, margins, and optimize processes. It is highlighted that, for the purposes of this academic work, a proposal of Vision, Mission, Values, and Code of Ethics will be made that involve the interests and demands that the Operation and Maintenance Services Sector in Oil and Gas asks of the participants of the industry (A. Robayo, N. Espinosa, O. Rodríguez, O. Fernández and O. Santos, 2015)

The rivalry existing in companies in an industry leads to sacrificing a certain degree of profitability in the sector and in the companies composing it. When an intense rivalry occurs, competitors adopt strategies such as entering a price war, constantly investing in infrastructure, advertising, and facilities, which causes an increase in costs and expenses that reduces the profit margin of companies (J. Sakr, R. Pallini, 2018).

As long as there are several competitors, the rivalry will be more intense, the competitors are similar in terms of size and power, the growth sector is slow, as it does not compete in a developing and growing market, the companies in the market must compete vigorously for a share, with high probability of exit and occurs when there are high levels of investment and costs invested in the industry and there is a high commitment to part of the companies in the sector for being leaders, this based on prestige or image issues (J. Sakr, R. Pallini, 2018, mention Porter 2008)

\section{METHODOLOGY}

The oil and gas industry has advanced technologically to improve its processes. In the 1950s, the industry focused on technologies to find and produce oil in areas with significant surface oil manifestations, processing the lightest possible crudes in refineries whose operation was very manual. In the 1980s, with the rise of 3D seismic exploration in geologically complex areas emerged with the development of horizontal wells and the support of information technologies. In addition, refinery diets and products were diversified, including the processing of medium crude, increased diesel production, and the environmental and process safety approach was reinforced.

The technological advances of the last decades have produced important changes in exploration, development, and production. Technology transformed the processes made them more efficient, effective, safe, and more careful of the environment. These circumstances lead to a radical change in the environment where companies must operate. Therefore, companies in the oil and gas market will have to redefine their strategies to be more competitive and survive in the future world. (Petrotechnics, 2015)

Today, technological challenges are focused on taking advantage of unconventional resources, increasing the recovery of existing fields, and using the increasingly powerful and portable resources of mass computing and 
wireless technologies; all of these with a strong focus on process safety, environmental management, and fuel quality.

In a new era of high oil and gas price, volatility, data and technology are crucial to help operators reduce costs and maximize value. It is well known that the oil industry is in a constant battle against low crude prices, stricter regulations, and other fuel and energy alternatives, as well as rising exploration costs. Many of the major oil-producing countries are struggling to break even in production costs, and most analysts believe the situation could worsen rather than improve.

In Peru, a Talara Refinery Modernization (PMRT) project was presented, which brings with it new knowledge and technology, generating innovation in the scheme of the industrial refining process.

The PMRT is the largest public investment project in the country's history with a total investment of US\$ 4.7 billion. This initiative, which actually consists of the construction of a new refinery, will allow the production of fuel with lower sulfur content, according to the demands of the international energy market. In addition, the processing capacity will be increased from 65,000 to 95,000 barrels per day and a technology will be implemented that will allow the more efficient processing of heavy crudes from the jungle. (Petroperú, 2019).

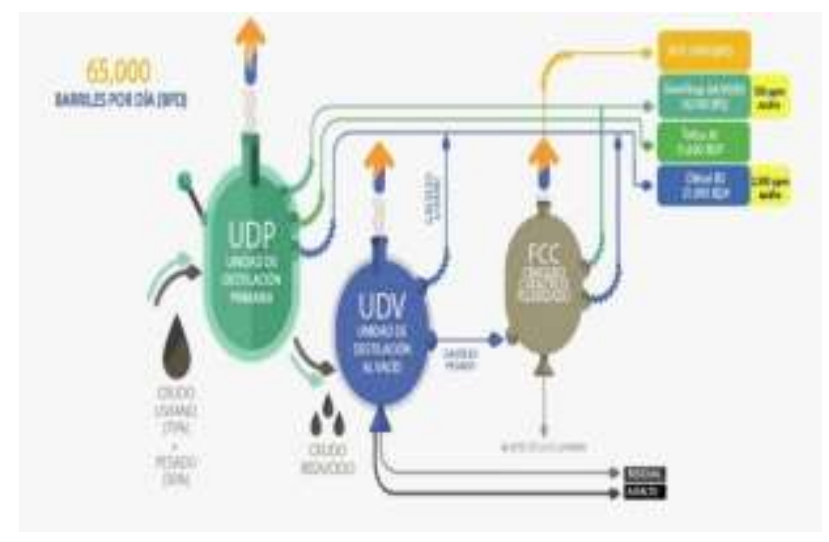

Figure 3: Production scheme before the PMRT (Petroperú, 2019).

Objectives of the PMRT

- $\quad$ Process 95,000 barrels of crude oil per day.

- $\quad$ Produce fuel (diesel, gasoline, and LPG) with low sulfur content.

- Processing of heavier crudes (domestic and imported).

- Deep conversion of waste to valuable products such as diesel, naphtha, and LPG (flexicoking).

- Conversion of low-octane gasoline into high-octane gasoline (Catalytic Reformation).

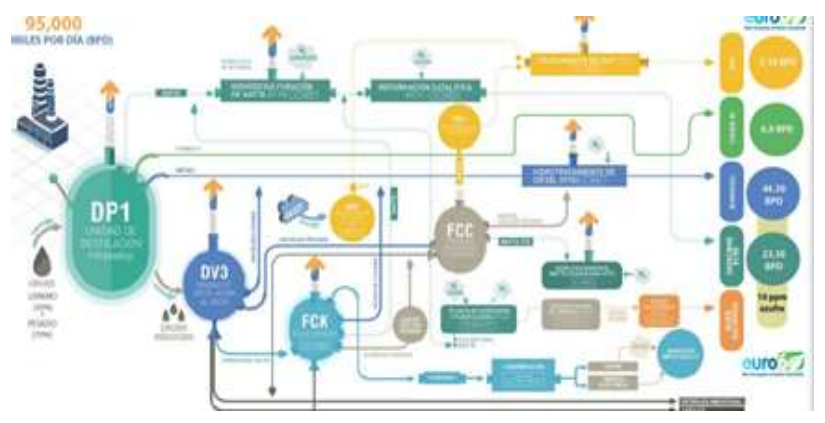

Figure 4: Production scheme after the PMRT (Petroperú, 2019). 
Description

\section{Facilities:}

- $100 \mathrm{MW} / 220 \mathrm{KV}$ backup power line.

- Administration, maintenance, and logistics buildings.

- New laboratory.

Dispatch and storage:

- $\quad$ New liquid loading dock - MU2. Modernizer existential dock MCL

- 21 New storage tanks (1.5 MMbbls).

- Instrumentation of existing tanks.

Process units:

- Physical separation of hydrocarbon mixtures by evaporation and condensation.

- Fuel desulfurization.

- Reformation: octane increase in gasoline.

- $\quad$ Conversion: heavy waste to light products (diesel, petrol, and LPG).

Auxiliary units:

- Provide hydrogen, nitrogen, water, electrical energy (100 MW), steam conversion of sulfur into sulfuric acid, and effluent treatment.

This is a contribution of technology to the profitability of the project, thanks to the processes of deep conversion and catalytic reformation. The new refinery would be one of 10 in the world to have flexicoking, a technology that, by allowing the processing of the heaviest waste streams generated in the refinery, would substantially raise the refining margins, guaranteeing the profitability of the project. (F. Rodriguez de Castillejo, A.,2019)

\section{RESULTS}

\subsection{National Context}

Over the past 20 years, Peru has witnessed major changes in the domestic oil and gas industry. Specifically, in the natural gas (NG) industry, the country's primary energy matrix changed, also, in oil there were price variations due to geopolitical and institutional changes in the country's economic structure.

In addition, considering the historical evolution of the industry, the technologies were perfected to exploit gas and oil are difficult areas to access, which is why they allowed to exponentially expand the world supply of hydrocarbons contributing to the development of the country, and at the same time being of relevance for the oil and gas industry for its important role in the Peruvian economy.

\section{CONCLUSIONS}

The hydrocarbon sector will be the main source of sustainable energy for years to come.

During the last years the methods of exploitation and production of gas and oil were changing, today we are committed to taking on challenges for new methods of extraction and commercialization in more complex lands and much more perceptible environmental partner environments.

In Peru, during the last years, the oil and gas industry presented changes, especially in natural gas (NG), and so on the new professionals falls great responsibility full of changes in the hydrocarbons sector.

Working between industry and state contributes to satisfactorily facing the technological challenges that Peru is going through.

The great limitation is not due to natural resources, but to the skills to respond to each need of the industry.

\section{RECOMENDATIONS}

It is necessary to create new technologies and compounds for the oil and gas industry. Having lighter, degradable and less polluting components is necessary to reduce the environmental impact.

It is advisable to use new technologies today that seek to use unconventional resources strengthening process safety, environmental management, and fuel quality. At the same time, it is recommended to continue promoting and implementing technologies to exploit gas and oil since they play an important role in the Peruvian economy. 


\section{REFERENCES}

[1] Javier Sakr, J. C. (n.d.). Sector hidrocarburos líquidos: influencia de los precios internacionales del petróleo en la competitividad empresarial de las actividades downstream en el Perú entre los años 2004 y 2016. https://doi.org/10.19083/tesis/625476

[2] Jesús Tamayo. (2020). La Industria de los Hidrocarburos Líquidos en el Perú. Osinergmin: Organismo Supervisor de la Inversión en Energía y Minería.

[3]Sociedad Privada de Hidrocarburos. (2021). Boletín Estadístico Mensual. SPH: Sociedad Privada de Hidrocarburos.

[4].Roxana A. Pallares (2015). Las nuevas tecnologías que pueden modificar la industria del petróleo y del gas. Petrotecnia.

[5]Carlos Paredes. Petroperú (2019). PMRT: Proyecto Modernización Refinería Talara.

[6] Fernando R. de Castillejo A. (n.d.). Ampliación de la Refinería Talara: Tecnologías del nuevo esquema de refinación. https://www.petroperu.com.pe/Docs/files/noticias/presentacion-pmrt.pdf

[7] Utrilla Salazar, D. (2014). Sistema de arquitectura multisensorial para supervisión y seguridad industrial aplicando tecnología de inteligencia http://alicia.concytec.gob.pe/vufind/Record/UNMS_eb475873ed3190ca2dd70fffdf4f5e87.

[8] Villafani Luyo, H. (2019). Principales determinantes de la inversión exploratoria en el sector hidrocarburos peruano: un análisis de $\quad$ series de tiempo. https://tesis.pucp.edu.pe/repositorio/bitstream/handle/20.500.12404/14636/VILLAFANI_LUYO_HUMBERTO _CROSS_PRINCIPALES_DETERMINANTES_INVERSION.pdf?sequence $=1 \&$ isAllowed $=\mathrm{y}$

[9] Robayo Carreño, A. H., Espinosa Garzón, N. G., Rodríguez Rodríguez, O. C., Fernández Moreno, O. J., \& Santos Castro, O. M. (2015). Planeamiento estratégico del sector de operación y mantenimiento en petróleo y gas. https://tesis.pucp.edu.pe/repositorio/bitstream/handle/20.500.12404/14503/ROBAYO_ESPINOSA_PLANEAM IENTO_PETROLEO.pdf?sequence=1\&isAllowed $=\mathrm{y}$

[10] Stefan Orszulik. (2016). Environmental Technology in the Oil Industry. https://link.springer.com/book/10.1007\%2F978-3-319-24334-4

11] ExxonMobil, 2001. Global Climate Change ExxonMobil.

http://www.exxonmobil.com/news/publications/c global climate change/c index.html, accessed February 2001. 